\title{
РОЛЬ СИМУЛЯЦІЙНИХ ТЕХНОЛОГІЙ У ПРОЦЕСІ ВИКЛАДАННЯ ТРАВМАТОЛОГІї ТА ОРТОПЕДІї
}

\author{
А. І. Цвях, І. С. Кулянда, І. Р. Копитчак, Ю. О. Грубар, Ю. С. Сморщок, \\ Н. О. Марченкова, Є. А. Лимар
}

\author{
ДВНЗ “Тернопільський державний медичний університет імені I. Я. Горбачевського \\ МОЗ Украӥни”
}

\section{THE ROLE OF SIMULATION TECHNOLOGIES IN THE TEACHING PROCESS OF TRAUMATOLOGY AND ORTHOPEDICS}

\author{
A. I. Tsvyakh, I. S. Kulyanda, I. R. Kopytchak, Yu. O. Hrubar, Yu. S. Smorshchok, \\ N. O. Marchenkova, Ye. A. Lymar \\ I. Horbachevsky Ternopil State Medical University
}

\begin{abstract}
У системі медичної освіти симуляційні технології лежать в основі ряду методик, покликаних допомагати відтворювати клінічні ситуації відповідно до мети навчання, повторення, оцінки і дослідження. У статті висвітлено питання застосування симуляційних технологій у системі викладання ортопедії та травматології для студентів 5 курсу медичного факультету й окреслено перспективи застосування симуляційного навчання для підготовки лікарів-інтернів. Впровадження симуляційних технологій навчання сприятиме кращому засвоєнню практичних навичок та хірургічних методик $з$ травматології.
\end{abstract}

In the system of medical education simulation technology is a basis of a number of techniques designed to help to reproduce the clinical situation in accordance with the purpose of training, repetition, evaluation and research. The article lit the application of simulation technologies in the system of teaching orthopedics and traumatology for 5th year students of the Medical Faculty and outlines the prospects of simulation training to prepare interns. Implementation of simulation training technologies facilitate better assimilation of practical surgery skills and techniques in traumatology.

Вступ. Постійне впровадження сучасних медичних технологій у практику охорони здоров’я, підвищення вимог до професійної компетентності медичних працівників визначають необхідність посилення практичного аспекту підготовки фахівців [1, 4]. Питання, як оволодіти хірургічною майстерністю не заподіявши шкоди хворому, посідає чи не ключове місце в системі хірургічної освіти. У той час як отримання теоретичних знань не складає великих труднощів, адже в розпорядженні студентів та лікарів-інтернів, курсантів є монографії, наукові статті, лекції, відеоматеріали, то практичний досвід завжди важко набути, а головне - він пов'язаний $з$ ризиком для реального пацієнта. Сучасні методики проведення навчання не здатні надати реальну картину операційного поля, не в змозі оцінити якість і точність рухів лікаря-початківця, зрештою, не можуть замінити реального оперативного втру-

() А. І. Цвях, І. С. Кулянда, І. Р. Копитчак та ін. чання. Донедавна альтернативою служили заняття з використанням лабораторних тварин, яких, як відомо, є недостатня кількість [1, 3]. Лікар хірургічного профілю, йдучи в операційну, повинен мати вже базові моторні навички. Єдиним ефективним i безпечним способом для відпрацювання початкових практичних умінь у цей час є застосування віртуальних тренажерів - систем, що моделюють реальну операцію й повністю імітують реакцію тканин на дії хірурга [1]. Лікарі, які освоюють практичні навички за допомогою тренажера, значно швидше і впевненіше переходять до справжніх втручань, їх подальші реальні результати стають більш професійними [2]. Основною метою застосування симуляторів під час вивчення хірургічної патології є імітація клінічних ситуацій, з приводу яких необхідно надати допомогу з можливістю багаторазового відпрацювання навичок і подальшим аналізом результатів [2, 3]. 
Основна частина. На кафедрі травматології та ортопедії з військово-польовою хірургією розроблені і впроваджені в практику методичні рекомендації та методичні вказівки згідно з темами, що виносяться для навчання в симуляційному центрі для студентів медичного й іноземного факультетів п’ятого курсу та лікарів-інтернів ортопедів-травматологів.

Згідно з розробленим планом, виділено для підготовки студентів п’ятого курсу одне двогодинне заняття в симуляційному центрі, метою якого є навчити накладати скелетний витяг та апарати зовнішньої фіксації на муляжі кісток верхніх та нижніх кінцівок. На практичному занятті кожен студент має змогу самостійно, під керівництвом викладача, опанувати методику практичної навички.

Робота в симуляційному центрі дозволяє студентам ознайомитись із основним набором хірургічних інструментів, необхідних для проведення скелетного витягу та накладання апаратів зовнішньої фіксації. Самостійне виконання практичних навичок під контролем викладача дає можливість краще підготовитись студентам до самостійного виконання даних хірургічних маніпуляцій.

Нами розроблено п’ять практичних занять для лікарів-інтернів ортопедів-травматологів, а саме:

Заняття № 1. Накладання скелетного витягу на верхні та нижні кінцівки.

Заняття № 2-3. Позавогнищевий остеосинтез. Іммобілізація та лікування переломів кісток за допомогою АЗФ (плече, передпліччя, кисть, кістки таза, стегно, гомілка, стопа).

Заняття № 4. Накістковий остеосинтез довгих трубчатих кісток (фіксація кісткових фрагментів за допомогою спиць, гвинтів, пластин).

Заняття № 5. Інтрамедулярний остеосинтез довгих трубчатих кісток.

Кожне заняття має відповідне матеріально-технічне забезпечення. На практичному занятті в симу-

\section{Список літератури}

1. Альберг Г. Відпрацювання ендохірургічних практичних навичок з використанням віртуальних технологій / Г. Альберг // Віртуальні технології в медицині. - 2009. № 1. - С. 7.

2. Дозорнов М. Г. Сучасні проблеми навчальних центрів та шляхи їх вирішення / М. Г. Дозорнов // Віртуальні технології в медицині. - 2010. - № 2. - С. 4-6. ляційному центрі всі лікарі-інтерни мають однакові можливості для засвоєння кожної практичної навички, що дає можливість адекватно оцінити попередній рівень підготовки кожного інтерна, здатність до оволодіння лікарем-інтерном певною навичкою.

Маючи можливість проводити певні маніпуляції на муляжах кісток, лікар-інтерн може відтворити найбільш типові ситуації, котрі виникають при травматологічних операціях. Зокрема, проводячи той чи інший вид остеосинезу, майбутній фахівець може візуально оцінити якість проведеного остеосинтезу. Маючи можливість контролювати положення кісткових уламків, лікар може оцінити стабільність фіксації останніх, можливість проведення, при необхідності, репозиції перелому при різних методах фіксації кісткових уламків.

Все це, в комплексі з демонстрацією відповідних рентгенограм, значно полегшує процес навчання лікарів-інтернів, дає можливість наглядно продемонструвати важливість дотримання етапів проведення остеосинтезу для досягнення стабільної фіксації кісткових уламків.

Можливість виконувати етапи оперативного лікування або формувати навички необхідну кількість разів до повного їх відпрацювання, створення рівних умов для всіх лікарів-інтернів та можливість індивідуального підходу до процесу навчання дозволяє краще підготувати лікаря-інтерна до самостійної операційної діяльності.

Висновки: 1. Проведення занять із студентами медичного факультету в симуляційному центрі необхідне для освоєння ними перших практичних навичок з травматології.

2. Засвоєння практичних навичок полегшує сприйняття теоретичного матеріалу.

3. Під час використання симуляційних технологій у навчальних процесах на факультетах післядипломної освіти лікар-інтерн набуває свій перший практичний досвід роботи.

3. Rosse C. Motivation and organizational principles for anatomical know) ledge representation / C. Rosse // The Digital Anatomist symbolic knowledge base. - 2009. Vol. 13, № 15. - P. 103-104.

4. Schenk M. P. Going digital: Image preparation for biomedical publishing / M. P. Schenk // Anat. Rec. (New Anat). - 2010. - Vol. 4, № 3/5. - P. 78-83. 